\title{
Damage to black locust leaves (Robinia pseudoacacia L.) by the black locust gall midge (Obolodiplosis robiniae) (Haldeman, 1847) in the Włoszczowa-Jędrzejów Protected Landscape Area - research on strengthening and developing knowledge and awareness in environmental education
}

\footnotetext{
*

Faculty of Science and Life Sciences at Jan Kochanowski University in Kielce, Poland,

* Faculty of Pedagogy and Psychology at Jan Kochanowski University in Kielce, Poland,

*** Faculty of Law and Social Sciences at Jan Kochanowski University in Kielce, Poland,

**** PHN S.A. in Warsaw, Poland, e-mail: gietkamar@gmail.com

***** Institute of Environmental Protection - National Research Institute in Warsaw, Poland, e-mail: j.chmielewski@ios.gov.pl
}

\section{Keywords:}

leaf damage, Robinia pseudoacacia L., insects, Włoszczowa-Jędrzejów Protected Landscape Area, Świętokrzyskie Province, awareness, environmental

\section{Abstract}

The prepared article by the team of authors aims to show research in the field of strengthening and developing knowledge and awareness from environmental education in the community of nature conservation services and the academic community. This paper is the result of research conducted in 2014-2015, in the WłoszczowaJędrzejów Protected Landscape Area, in the Świętokrzyskie Province. The material for the study was acacia robinia (Robinia pseudoacacia L.) leaves collected on two research areas, differentiated due to the influence of anthropogenic factors. As a result of the study, 5,000 black locust leaves were collected, $65 \%$ of which were found to be damaged. Research stands under the influence of strong anthropopressure were characterised by a higher number of lesions on leaves.

(c) IOŚ-PIB

\section{INTRODUCTION}

The work presented below addresses the aspect of enhancing and developing knowledge, to conduct environmental education and create awareness among employees of nature services and the academic community. It is justified to describe particular elements of knowledge on the natural environment, which allows us to understand natural phenomena as well as their complexity and causes necessary determination to undertake activities and behaviours characterised by sensitivity to environmental problems. The awareness that nature gives us allows us to perceive the dimension of existence and man's responsibility for the environment in a broader way. There is no doubt that the level of environmental awareness should always be raised, and knowledge should be broadened and supplemented with a specific range of topics. One's ecological imagination and value system must be consistently shaped towards learning about activities and actions that improve our environment. It is also important to identify and reveal forms of interference that have a negative impact on the environment.

A key element is the combination of environmental awareness as well as the perception of aspects of environmental education in terms of content, in constantly increasing knowledge on threats to natural elements. On the basis of knowledge, it is worth pointing out the mechanisms of threats, especially in the face of increasing, nowadays, strong anthropopressure. 
Black locust (Robinia pseudoacacia L.) is a species of deciduous tree which belongs to the Fabaceae family. It originated in North America and is widespread throughout the world. It is readily found in dry and warm places, in widespread forests, thickets and mid-field woodlots. False Acacia is an invasive species that is difficult to control and significantly impacts habitat alteration. It has the ability to dry out the deeper layers of the substrate, while enriching the surface layer with nitrogen. It is a light-loving plant with low soil requirements.

In Poland, it belongs to the fully acclimated trees, occurring mainly in the western and southern parts of the country [Wojda et al. 2015].

Like any plant, Black locust is exposed to various biotic and abiotic factors. Insects, mainly dipterans belonging to the pimple fly family (Cecidomyiidae), are dangerous pests found on this tree. They are small insects with a slender body structure, usually having a red translucent abdomen. Members of this family have long antennae covered with bristles and broad wings with reduced yellow, orange or red venation [Skrzypczyńska 1996].

Some pest species are pests of cereals and vegetables, while others damage coniferous and deciduous trees. Mainly, the larvae of these insects form various kinds of deformations (growths, cecydium) on plants. The mechanism of outgrowth formation involves uneven growth of plant tissue, stimulated by chemicals secreted by the larvae [Molnár et al. 2009]. One such species is the black locust gall midge (Obolodiplosis robiniae) (Haldeman 1947) (Diptera: Cecidomyiidae), an alien species to the native fauna. It originates from the home country of the Black locust, namely the central and western parts of North America. Currently, this pest has spread to many European countries, also to Japan, China and South Korea [Kodoi et al. 2003; Woo et al. 2003]. On the European continent, $O$. robiniae has been recorded since 2003; currently, its range extends from France to Ukraine and from Sweden through Denmark, Great Britain in the north to Albania, Macedonia, and southern Italy [Duso and Skuhravá 2003; Berest 2006; Skuhrava et al. 2007, 2008; Yao et al. 2015]. This insect colonises robinia trees of different age and condition, found both in tree canopies of natural origin and planted in urban parks and gardens [Duso et al. 2011]. In Poland, the presence of this species was first recorded in 2007 in Kraków [Skrzypczyńska 2007]. The above-mentioned author in her study gives a list of 89 species of hornworms collected from eight regions of southern Poland. These dipterans were found on 54 host plants. The black locust gall midge (Obolodiplosis robiniae) together with another beetle Janetia cerris (Kolla, 1850) - are reported as new species for the Polish fauna. Currently, the black locust gall midge is widely distributed throughout the Southwest. It has now also been demonstrated from the north-eastern area of the country [Kostro-Ambroziak and Mieczkowska 2017]. Due to the rapid rate of spread of this insect, its expansion should be controlled, especially in protected areas.

The aim of this study is to carry out a qualitative and quantitative analysis of outgrowths caused by the black locust gall midge (Obolodiplosis robiniae) in tree stands of varying degrees of anthropopressure intensity, occurring in protected areas in the Świętokrzyskie Province.

\section{STUDY SITE}

Areas of protected landscape are zones protected because of their distinctive landscape with diverse ecosystems, valuable for the possibility of satisfying needs related to tourism and recreation or fulfilling the function of ecological corridors (the Nature Conservation Act).

One of many such locations is the Włoszczowa-Jędrzejów Area of Protected Landscape (W-JOChK). It is in the western and central part of the Świętokrzyskie Province and covers an area of $703.89 \mathrm{~km}^{2}$. As one of several Protected Landscape Areas, it is part of the Przedborski Landscape Park. Two sites were delineated in the study area that were differentiated by anthropogenic influence.

Test Site 1 was located approximately $4 \mathrm{~km}$ north of the village of Czarnca, located within the W-JOChK. Topographically, it is a flat area with a southern exposure. The study material is from trees adjacent to various sources of environmental pollution. From the north site is the 'Strunobet' concrete factory, to the west is a provincial road with heavy traffic, and to the south of the described area runs a railway line (Fig. 1).

Test Site 2, situated within the W-JOChK, is in the southern part of Kurzelów, approximately $3 \mathrm{~km}$ from the village centre. Topographically, it is a western exposure with insignificant slope. The tree layer, apart from Black locust, is dominated by Scots pine (Pinus sylvestris) and occasionally oaks (Quercus spp.). The species of the herbaceous undergrowth are bilberry (Vaccinium myrtillus), cowberry (Vaccinium vitis-idaea), wild strawberry (Fragaria vesca) and others. The trees from which the material under study was collected are in the vicinity of a forest road (Fig. 1).

\section{RESEARCH MATERIAL AND METHODS}

The material for this study was black locust (Robinia pseudoacacia L.) leaves collected during July and August 2014-2015 in two study sites in the W-JOChK.

The leaf of the black locust consists of the leaf blade, petiole and the leaf base. False acacia leaves have a leaf blade of the compound (pinnate) type, consisting of several leaf blades called pinnules (Fig. 2). Acacia's leaves reach 15-20 $\mathrm{cm}$ in length and consist of 9-27 oval or elliptical pinnules [Szweykowska and Szweykowski 2008].

Black locust leaves were collected in early August 2014 and late July in 2015. In the first year of the study, the material came from 10 trees, while in the second year it came from 15 trees. The selection of trees, from which material for the study was obtained, was random. The trees were about 4-5 m tall with a diameter at breast height of $30-40 \mathrm{~cm}$ and 100 leaves were collected from each tree.

The collected material was placed in the laboratory conditions, then analysed. The number of harvested black locust leaves, including damaged leaflets (with 


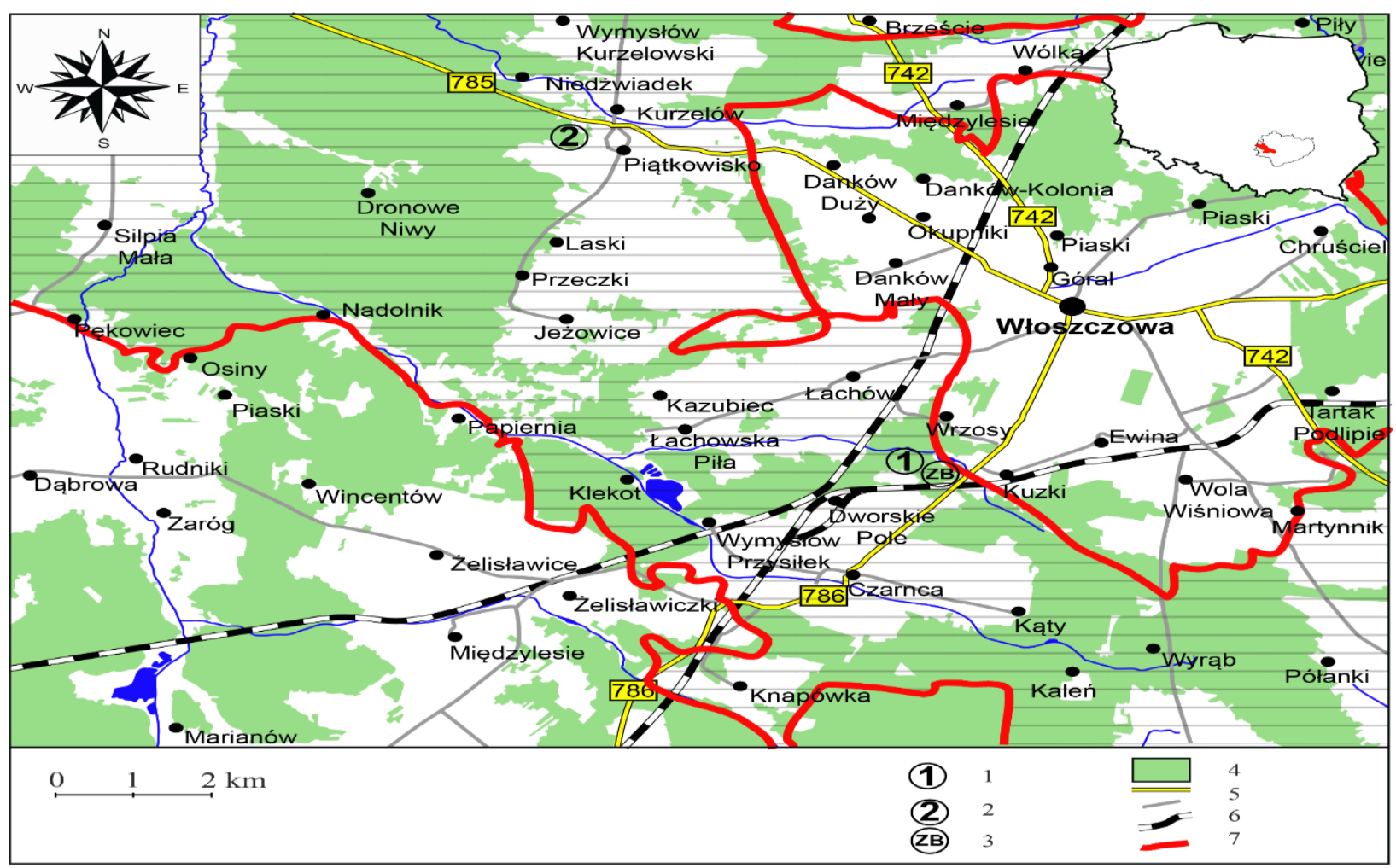

Figure 1. Study area: 1 - Czarnca site, 2 - Kurzelów site, 3 - 'Strunobet' concrete factory, 4 - forest areas, 5 - roads, 6 railway line, 7 - the area of the Włoszczowa-Jędrzejów Protected Landscape Area (Own elaboration)

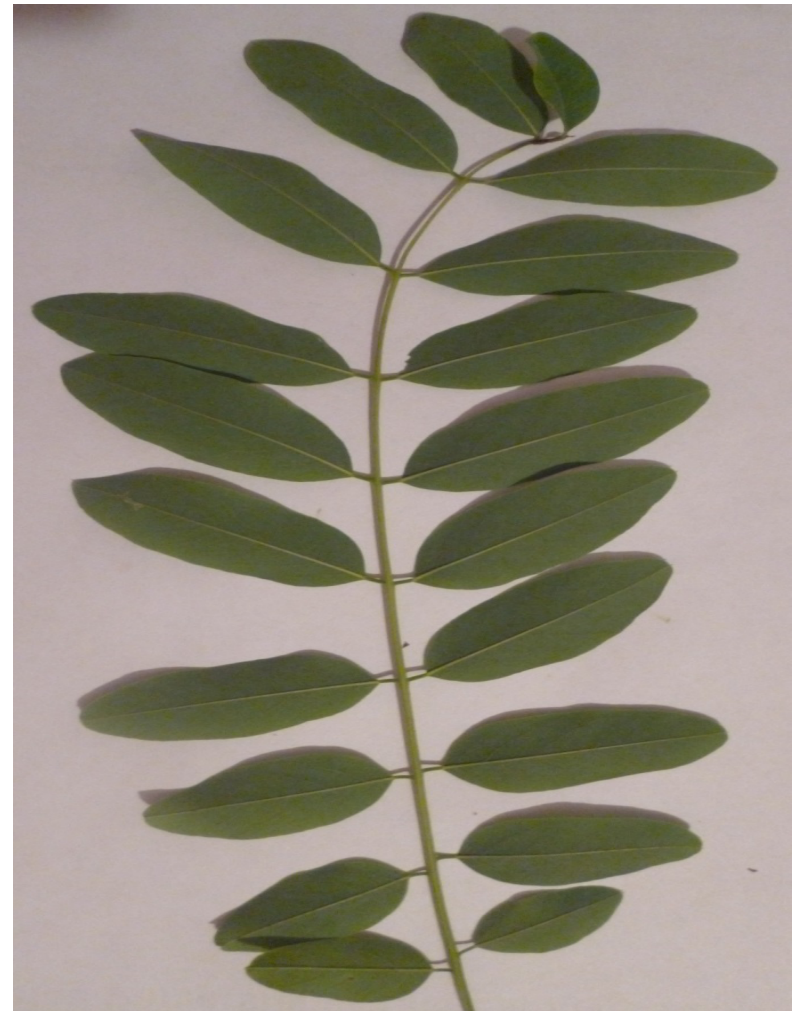

Figure 2. Black locust (Robinia pseudoacacia L.) leaf (photo. B. Matyśkiewicz). outgrowths), the number of leaves with outgrowths and the number of present outgrowths were determined. The affected leaves had a swollen edge, curled downwards. The study by Skuhravá et al. (2007) was used to evaluate the material.

In order to compare the severity of growths across sites, the formula for calculation of the index $(F)$ of the incidence of outgrowths [Segebade and Schaefer 1979] was used.

$$
\mathrm{F}=\frac{\mathrm{z}}{\mathrm{n}} \mathrm{x} \text { a } \mathrm{xd}
$$

where: $\mathrm{z}$ - the number of leaves with outgrowths, $\mathrm{n}$ number of leaves tested, a - share of attacked leaves in relation to all analysed leaves, $\mathrm{d}$ - the average number of outgrowths per affected leaf.

A colonization index was also used to compare the colonization of leaves by outgrowths [Kapuściński 1966]. - absolute

The number of outgrowths

The number of all leaves in the sample

- relative

The number of outgrowths

The number of damaged leaves in the sample 
Table 1. Analysis of collected material at study sites in 2014-2015

\begin{tabular}{|c|c|c|c|c|c|c|c|} 
Site & $\begin{array}{c}\text { Number } \\
\text { of } \\
\text { leaves }\end{array}$ & $\begin{array}{c}\text { Number } \\
\text { of leaves } \\
\text { with } \\
\text { outgrowth }\end{array}$ & $\begin{array}{c}\text { Number } \\
\text { of } \\
\text { pinnules } \\
\text { on leaves }\end{array}$ & $\begin{array}{c}\text { Number of } \\
\text { leaflets with } \\
\text { outgrowths }\end{array}$ & $\begin{array}{c}\text { Number of } \\
\text { outgrowths } \\
\text { on leaflets }\end{array}$ & $\begin{array}{c}\text { Average } \\
\text { number of } \\
\text { outgrowths } \\
\text { per leaf }\end{array}$ & $\begin{array}{c}\text { Average } \\
\text { number of } \\
\text { outgrowths } \\
\text { per leaflet }\end{array}$ \\
\hline Czarnca & 2,500 & 1,985 & 36,352 & 6,856 & 8,783 & 4.4 & 1.3 \\
\hline Kurzelów & 2,500 & 1,254 & 39,139 & 1,789 & 2,838 & 2.3 & 1.6 \\
\hline & & $(50.2 \%)$ & & $(4.8 \%)$ & & & \\
\hline Total & 5,000 & 3,239 & 75,491 & 8,645 & 11,621 & & 3.6 \\
\hline
\end{tabular}

Source: Own elaboration

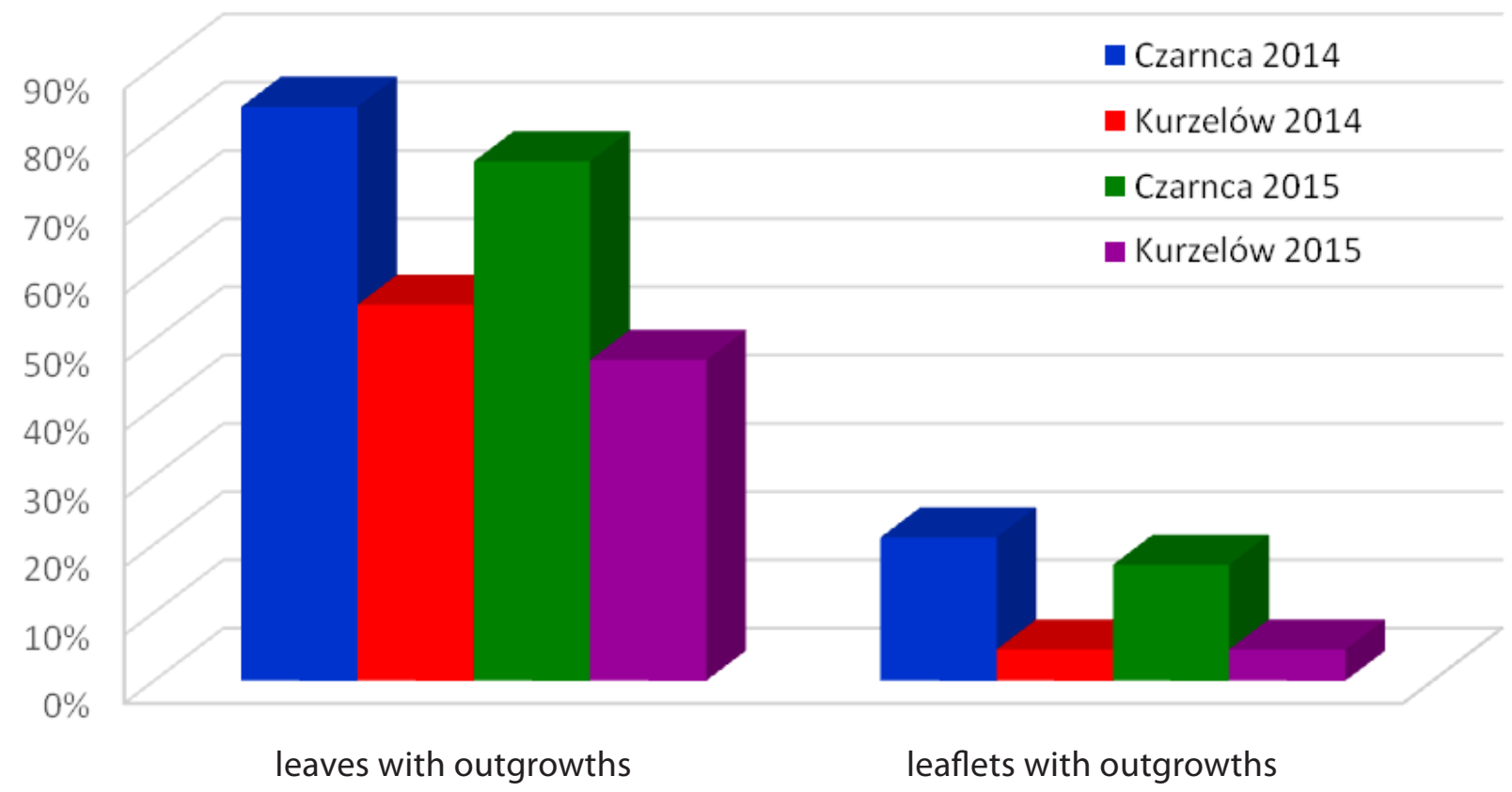

Figure 3. Analysis of acacia robinia leaves and leaflets with outgrowths, on the Czarncy and Kurzelów sites, in successive years of the study

Source: own elaboration

\section{RESULTS OF THE RESEARCH AND THE DISCUSSION}

The analysis of 5,000 leaves of Robinia pseudoacacia L., consisting of 75,491 leaflets, collected on both study sites during the two study seasons showed that 3,239 leaves (64.8\%) had outgrowths. Of the 75,491 leaves, damage in the form of 11,621 outgrowths was found on 8,645 .The number of leaves with outgrowths ranged from $4.8 \%$ in the Kurzelów locality to $18.9 \%$ in Czarnca.

The average number of outgrowths per analysed leaf ranged from 2.3 in Kurzelów to 4.4 in Czarnca, whereas the average number of outgrowths per leaf on both study sites were similar and fluctuated between 1.3 and 1.6 (Tab. 1).

Analysing the data in subsequent years, it was found that in the first year of the study (2014) in the test site located in Czarnca, among 1,000 leaves collected $-84.1 \%$ were damaged, and the total number of leaves examined in this area was 15,054 ( $21 \%$ were damaged leaves). As a result of the survey conducted in 2014 in the Kurzelów area, 1,000 leaves were collected, of which 551 had impairments, representing $55.1 \%$. They consisted of 16,232 leaflets, among which 741 (4.6\%) had outgrowths (Fig. 3). 
Table 2. Frequency index of the occurrence of outgrowths (F) on black locust leaves at sites in Czarnca and Kurzelów in 2014-2015

\begin{tabular}{|c|c|c|}
\hline \multirow{3}{*}{ Site } & Year & F \\
\hline \multirow{3}{*}{ Czarnca } & 2014 & 0.22 \\
\cline { 2 - 3 } & 2015 & 0.18 \\
\cline { 2 - 3 } & $2014-2015$ & 0.2 \\
\hline \multirow{3}{*}{ Kurzelów } & 2014 & 0.04 \\
\cline { 2 - 3 } & 2015 & 0.04 \\
\cline { 2 - 3 } & $2014-2015$ & 0.03 \\
\hline
\end{tabular}

Source: Own elaboration

Table 3. Indicators of black locust leaves colonisation by the black locust gall midge at test sites in 2014 and 2015.

\begin{tabular}{c|c|c|c|} 
Site & Year & $\begin{array}{c}\text { Absolute } \\
\text { colonisation } \\
\text { index }\end{array}$ & $\begin{array}{c}\text { Relative } \\
\text { colonisation } \\
\text { index }\end{array}$ \\
\hline \multirow{3}{*}{ Czarnca } & 2014 & 0.29 & 1.33 \\
\cline { 2 - 4 } & 2015 & 0.21 & 1.24 \\
\cline { 2 - 4 } & $2014-2015$ & 0.24 & 1.28 \\
\hline \multirow{3}{*}{ Kurzelów } & 2014 & 0.08 & 1.66 \\
\cline { 2 - 4 } & 2015 & 0.07 & 1.54 \\
\cline { 2 - 4 } & $2014-2015$ & 0.07 & 1.59 \\
\hline
\end{tabular}

Source: Own elaboration

In 2015, 1,500 leaves were collected in the Czarnca test site, of which 1,144 were damaged (76\%), and the total number of leaves examined at the site was 21,298 (17\% were damaged leaves). In Kurzelów, 1,500 leaves were collected in 2015 , of which 703 had damage, which was $47 \%$. The total number of leaves was 22,907. On 1,048 (4.6\%) leaves, outgrowths were found (Fig. 3).

Pinnules from trees growing on the Czarnca site (in both years of the study) were characterised by higher values of the pest frequency index, 0.22 (2014) and 0.18 (2015), respectively. The value of the index in both years in Kurzelów was the same and amounted to 0.04 (Tab. 2).

The absolute and relative values of settlement rates differed significantly across Kurzelów. The disproportions between these indicators were not as great as in the case of the Czarnca area (Tab. 3).

The absolute index of the black locust leaf colonization, collected from trees growing in Czarnca in 2014, was 0.29, while the relative index had a value of 1.33 . The material from the same area, collected in the following year, was characterised by slightly lower values of 0.21 - (absolute index) and 1.24 (relative index), respectively. In Kurzelów, in 2014-2015, the absolute rates of black locust leaf colonisation were close to each other at 0.08 and 0.07 , respectively. There were greater differences in relative colonisation rates, with values as follows: 1.66 (2014) and 1.54 (2015) (Tab. 3).

Studies conducted in 2014-2015 on the colonisation of false acacia (Robinia pseudoacacia) leaves by the black locust gall midge (Obolodiplosis robiniae) allow us to conclude that the mentioned pest significantly leads to damage black locust leaves (Fig. 4). At the Czarnca site in 2014 , this species colonised $84.1 \%$ of the collected acacia's leaves, and $76 \%$ a year later. The material collected from the Kurzelów area had much less impairment. In 2014, about $55 \%$ of the acacia leaves collected were damaged and in 2015, material in the best health condition (47\%) was obtained.

During a two-year study it was found that on the leaves of acacia growing in the vicinity of the 'Strunobet' concrete factory near Czarnca, six times more often the outgrowths caused by the black locust gall midge occurred than on the leaves from the Kurzelów area -0.2 and 0.03 , respectively. Differences in values of occurrence frequency index in subsequent years were noted mainly at the Czarnca site. According to Skrzypczyńska (2001), the frequency of occurrence of outgrowths on plants undergoes significant changes in time and space. Many factors may influence the frequency of occurrence of outgrowths, e.g. the system of meteorological conditions and biotic factors, including parasitoids.

Studies concerning damage to leaves of black locust were conducted in 2015-2016, also in other protected areas located in Świętokrzyskie Province. These were four sites located in the Jeleniów and Cisowsko-Orłowiński Landscape Park (Bąk-Badowska - in preparation). The comparative material was collected in the vicinity of busy transport routes, Bituminous Plant and Mineral Raw Materials Mine 'Józefka' near Górno and in the area where anthropogenic pressure was insignificant (forest areas). Also in this study, an increased number of outgrowths caused by Obolodiplosis robiniae was shown on the leaves of robinia trees growing on sites heavily influenced by pollution.

According to the research conducted in 2015 in Podlasie, on sites located in towns and villages, the black locust gall midge caused a high level of leaf infestation there [KostroAmbroziak and Mieczkowska 2017]. Galls of this species were found on about $18 \%$ of leaves in compound leaves of false acacia; on average, 3.5 outgrowths per compound leaf (1-5 per leaf), with leaf infestation by 0 . robiniae in cities, in an area with significant pollution, being two times higher. It was shown that at least two generations of the black locust gall midge per year developed on the studied sites. The authors also demonstrated the presence of the endoparasitoid Platygaster robiniae Buhl and Duso (Hymenoptera: Platygastridae), previously described by Buhl and Duso (2008). This parasitoid has also been found in Switzerland [Wermelinger and Skuhravá 2007]. Field studies conducted by Lu et al. (2010) in Qinghuangdao (China) showed that the parasitism rate of this parasitoid can reach as high as $84 \%$; thus, it is of great importance in biological control. 


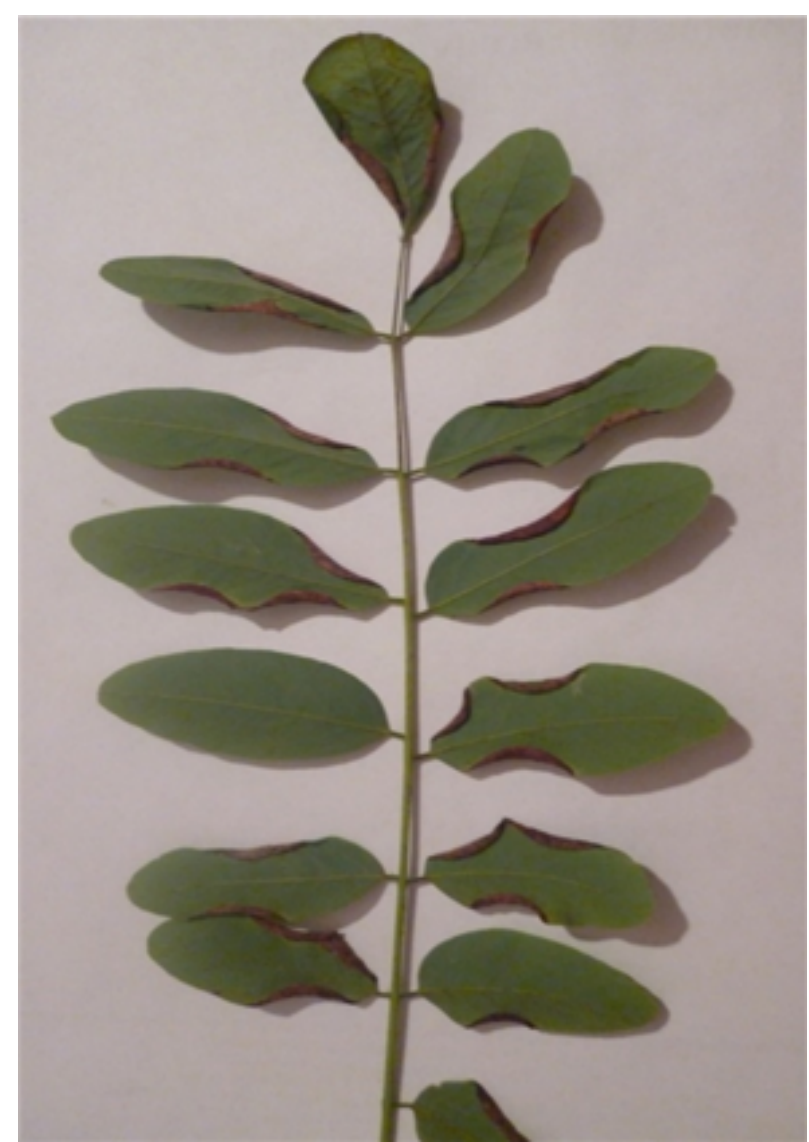

Figure 4. Black locust leaf with an impairment (photo B. Matyśkiewicz)

Studies on the co-occurrence of the black locust gall midge and other robinia leaf-mining insects, including butterflies of the Cibitiniidae family (Gracilliariidae), were conducted in our country in 2014 (Opole Province). On 31 test sites, divided according to their location and habitat conditions into three groups, leaves colonised by the black locust gall midge were collected: (1) urban, i.e. located in the urbanised areas of Opole; (2) rural - forming part of the mid-field and roadside woodlots, and (3) forest, located in woodlands. The outgrowths caused by the pest were present on the surveyed trees of all sites. A total of 1,277 leaves were collected on which 5,962 outgrowths were found. It was shown that forest sites had more outgrowths than urban sites. Mines caused by Phyllonorycter robiniella and Parectopa robiniella butterflies were found mainly in rural and forest test sites. The highest number of trees colonised simultaneously by $O$. robiniae and Phyllonorycter robiniella was on forest sites, while those colonised by $O$. robiniae and Parectopa robiniella were on rural sites [Olszanowska-Kuńka 2019]. At high incidence, the black locust gall midge may cause deformation of the tree assimilation apparatus and negatively affect the decorative values of robinia. Moreover, it has been observed that the leaf deformation outgrowths create favourable conditions for the development of pathogenic fungi, e.g. Coniothyrium insitivum Sacc. and Alternaria circianons (Beck.: Cyrt.) Boll, which causes leaf blackening and premature leaf fall [Kosibowicz 2009].

The economic importance of acacia robinia in our country is low. However, its role as an ornamental tree in parks and gardens, as well as its ability to provide a benefit to bees and other pollinating insects, is important. The use of herbal material from this tree in herbal medicine is also not without significance.

\section{CONCLUSIONS}

1. On the investigated plots located within the area of the W-JOChK, the black locust gall midge (Obolodiplosis robiniae) damaged $64.8 \%$ of the white robinia (Robinia pseudoacacia) leaves.

2. The material from the Czarnca locality, an area close to the 'Strunobet' concrete factory, a provincial road with heavy traffic and a railway line, had more damaged leaves $(79.4 \%)$ than that from the Kurzelów locality (50.2\%).

3. The average number of outgrowths per leaf in Czarnca was 4.4, while in Kurzelów it was 2.3.

4. The leaf colonisation indices were higher on trees growing in an area with greater anthropogenic influence.

5. It is necessary to continue the research on the expansion of the black locust gall midge in our country, because it is a species that increases its range of occurrence and reduces the aesthetic value of trees.

6. It is advisable to disseminate the obtained results among the employees of environmental protection services, e.g. foresters, who deal with forest protection and the discussed issues. It should be considered while creating forest protection plans and protection tasks in the above-mentioned range.

7. It is necessary to carry out further scientific research in this area and to define methods and ways of nature conservation, in terms of the effectiveness of protection activities and recognition of biodiversity of habitats.

8. It seems advisable to disseminate the obtained results among the academic community, including people dealing with the above issues, e.g. entomologists, ecologists and students from nature protection circles. 


\section{REFERENCES}

BEREST Z. L. 2006. The discovery of the gall-midges Obolodiplosis robiniae (Diptera, Cecidomyiidae) in Ukraine. Vestnik Zoologii 40, 6: 534.

BUHL P. N., DUSO C. 2008: Platygaster robiniae $\mathrm{n}$. sp. (Hymenoptera: Platygastridae) Parasitoid of Obolodiplosis robiniae (Diptera: Cecidomyiidae) in Europe. Annals of the Entomological Society of America 101, 2: 297-300.

DUSO C., BOARIA A., SURIAN L., BUHL P. N. 2011. Seasonal Abundance of the Nearctic Gall Midge Obolodiplosis robiniae in Italy and the Impact of Its Antagonist Platygaster robiniae on Pest Populations. Annals of the Entomological Society of America 104, 2: 180-191, DOI: 10.1603/AN10030.

DUSO C., SKUHRAVÀ M. 2003. First record of Obolodiplosis robiniae (Haldeman) (Diptera Cecidomyiidae) galling leaves of Robinia pseudoacacia L. (Fabaceae) in Italy and Europe. Frustula Entomologica 25, 38: 117-122.

KAPUŚCIŃSKI S. 1966. Szkodniki owadzie nasion drzew leśnych. PWRiL, Warszawa.

KODOI F., LEE H.-S., UECHI N., YUKAWA J. 2003. Occurrence of Obolodiplosis robiniae (Diptera: Cecidomyiidae) in Japan and South Korea. Esakia 43: 35-41.

KOSIBOWICZ M. 2009. Nowy szkodnik robinii. Las Polski 2: 20.

KOSTRO-AMBROZIAK A., MIECZKOWSKA A. 2017. Pierwsze stwierdzenie pryszczarka robiniowego Obolodiplosis robiniae (Haldeman, 1847) (Diptera: Cecidomyiidae) w północno-wschodniej Polsce. Wiadomości Entomologiczne 36: 126-127.

LU CH. K., BUHL P., DUSO C., ZHAO CH. M., ZHANG J. S., J Z. X., GAO S. H., JUJ. Y., WEN X. L. 2010. First discovery of Platygaster robiniae (Hymenoptera: Platygastridae) parasitizing the invasive Obolodiplosis robiniae (Diptera: Cecidomyiidae), a gall maker in China. Acta Entomologica Sinica 53: 233-237.

MOLNÀR B., BODDUM T., SZÖCS G., HILLBUR Y. 2009. Occurrence of two pest gall midges, Obolodiplosis robiniae (Haldeman) and Dasineura gleditchiae (Osten Sacken) (Diptera: Cecidomyiidae) on ornamental trees in Sweden. Entomologisk tidskrift 130: 113-120.

OLSZANOWSKA-KUŃKA K. 2019. Współwystępowanie pryszczarka robiniowego Obolodiplosis robiniae (Haldeman, 1847) (Diptera: Cecidomyiidae) z motylami minującymi liście robinii akacjowej. Opole Scientific Society, Fragmenta Naturae 52: 1-9.

SEGEBADE R., SCHAEFER M. 1979. Zur Ökologie der Arthropodenfauna einer Stadtlandschaft und ihrer Umgebung. II. Pflanzengallen und Pflanzenminen, Anzeiger für Schädlingskunde Pflanzenschutz, Umweltschutz 52: 117-121.
SKRZYPCZYŃSKA M. 1996. Owady - szkodniki nasion i szyszek drzew iglastych. Wyd. Gutenberg, Kraków.

SKRZYPCZYŃSKA M. 2001. Badania częstości populacji owadów i pajęczaków powodujących wyrośla na liściach buka pospolitego Fagus sylvatica L. w południowej Polsce. Acta Agraria et Silvestria ser. Silvestris 39: 195204.

SKRZYPCZYŃSKA M. 2007. Muchówki pryszczarkowate (Diptera: Cecidomyiidae) na wybranych stanowiskach w południowej Polsce. Dipteron 23: 26-33.

SKUHRAVÀ M., SKUHRAVÝ V., CSÓKA G. 2007: The spread of the invasive North American gall midge Obolodiplosis robiniae in Europe. Cecidology 22: 84-90.

SKUHRAVÀ M., SKUHRAVÝ V., SKRZYPCZYŃSKA M., SZADZIEWSKI R. 2008. Gall midges (Cecidomyiidae, Diptera) of Poland - a zoogeografical analysis. Annals of the Upper Silesian Museum (Entomology) 16:5-160.

SZWEYKOWSKA A., SZWEYKOWSKI J. 2008. Botanika. PWN, Warszawa.

Ustawa z dnia 16 kwietnia 2004r. o ochronie przyrody (Dz. U. Nr 92. poz.55).

WERMELINGERB.,SKUHRAVÀM.2007.Firstrecords of the gall midge Obolodiplosis robiniae (Diptera, Cecidomyiidae) and its associated parasitoid Platygaster robiniae Buhl \& Duso (Hymenoptera, Platygastridae) in Switzerland. Mitteilungen der Schweizerischen Entomologischen Gesellschaft 80: 217-221.

WOJDA T., KLISZ M., JASTRZĘBOWSKI A., MIONKOWSKI M., SZYP-BOROWSKA I., SZCZYGIEt K. 2015. The geographical distribution of the black locust (Robinia pseudoacacia L.) in Poland and its role on non-forest land. Papers on Global Change IGB, 22, 1:101-113, DOI: 10.1515/igbp-2015-0018.

WOO K. S., CHOE H. J., KIM H. J. 2003. A report on the occurrence of yellow locust midge Obolodiplosis robiniae (Haldeman, 1987) from Korea. Korean Journal of Applied Entomology 42: 77-79.

YAO Y., ZHAO W., SHANG X. 2015. Development of Polymorphic Microsatellite Markers of Obolodiplosis robiniae (Haldeman) (Diptera: Cecidomyiidae), a North American Pest Invading Asia. Journal of Insect Science 15, 1: 127. 